\title{
Faktor Risiko Anemia pada Wanita Pemetik Teh
}

\author{
Anemia Risk Factors in Female Tea Pickers
}

\author{
Eryasih Setyorini, Faisal Anwar*, Hadi Riyadi, Ali Khomsan \\ Departemen Gizi Masyarakat, Fakultas Ekologi Manusia (FEMA), Institut Pertanian Bogor \\ ('faisalanwar_gmipb@yahoo.com)
}

\begin{abstract}
ABSTRAK
Anemia dikenal sebagai masalah kesehatan masyarakat selama bertahun-tahun, berdasarkan hasil Riskesdas 2018 diketahui prevalensi anemia sebesar 48,9\%. Penelitian ini bertujuan menganalisis faktor risiko yang memengaruhi terjadinya anemia pada wanita pemetik teh di daerah Pengalengan Bandung, Jawa Barat. Desain penelitian adalah cross-sectional dengan 148 subjek Wanita Usia Subur (WUS) berusia antara 18-45 tahun yang sudah menikah dan tidak sedang hamil yang dipilih secara purposive di Kebun Purbasari, Talun Santosa dan Sedep. Penelitian ini merupakan bagian dari penelitian yang didanai oleh Neys-van Hoogstraten Foundation (NHF). Data yang diperoleh adalah karakteristik subjek (usia, besar keluarga, lama dan tingkat pendidikan), pengeluaran pangan dan non pangan keluarga/bulan, status gizi dan komposisi tubuh, dan status anemia. Hasil penelitian menunjukkan sebagian besar pekerja wanita pemetik teh berusia 40-44 tahun, dengan jumlah keluarga $\leq 4$ orang dan 72,3\% dengan tingkat pendidikan rendah (89,9\% berpendidikan maksimal SD). Rata-rata pengeluaran non pangan lebih besar daripada pengeluaran pangan. Berdasarkan berbagai indikator komposisi tubuh, secara umum pekerja wanita pemetik teh dalam kondisi berat badan berlebih (56,8\%), lingkar lengan atas normal (98,6\%). Rata-rata total lemak tubuh $>32,1 \%$, visceral fat normal $(\leq 9 \%$ ), lingkar pinggang berisiko $\geq 80 \mathrm{~cm}$, dan RPP $\geq 0,8 \mathrm{~cm}$ sebesar $81,1 \%$. Prevalensi anemia pada wanita pemetik teh sebesar $42,6 \%$. Overweight merupakan faktor yang paling berisiko terhadap anemia karena penimbunan lemak dapat menurunkan penyerapan zat besi sehingga jumlah hemoglobin menurun dan eritrosit mengecil. Umur sebagai faktor protektif. Anemia dapat dicegah melalui edukasi gizi, pola hidup sehat, dan pengendalian faktor penyebab serta predisposisinya.
\end{abstract}

Kata kunci : Anemia, faktor risiko, overweight, WUS

\section{ABSTRACT}

Anemia is known as a public health problem for many years, based on the results of Riskesdas 2018 it is known that the prevalence of anemia is $48.9 \%$. This research aims to analyze the risk factors that influence anemia in female tea pickers in Pangalengan, Bandung, West Java. The research method was cross-sectional with 148 subjects of the so-called Wanita Usia Subur (WUS). They are women of childbearing age, between 18-45 years old who were married and not pregnant. They were selected purposively in the plantation areas Purbasari, Talun Santosa and Sedep. This research was part of a research funded by Neys-van Hoogstraten Foundation (NHF). The data obtained are the characteristics of the subjects (age, family size, length and level of education), monthly family expenses for food and non-food, status of nutrition and body composition, and anemia status. The results showed that most of the female tea pickers are 40-44 years old, having family size up to 4 people and $72.3 \%$ of them are low level educated (89.9\% has maximum the elementary school education). The average expenses for non-food are greater than those for food. Based on various body composition indicators, the female tea pickers were in general overweight (56.8\%), normal upper arm circumference (98.6\%). The average total of body fat is greater than $32,1 \%$, normal visceral fat $(\leq 9 \%)$, waist circumference at risk $\geq 80 \mathrm{~cm}$, and $R P P \geq 0.8 \mathrm{~cm}$ at $81.1 \%$. The prevalence of anemia in tea picking women was $42.6 \%$. Overweight is the most risk factor for anemia because fat accumulation can reduce iron absorption so that the amount of hemoglobin goes down and erythrocytes decreases. The age as a protective factor. Anemia can be prevented through nutrition education, healthy lifestyles, and controlling the causes and predisposing factors.

Keywords : Anemia, risk factors, overweight, WUS 


\section{PENDAHULUAN}

Anemia dikenal sebagai masalah kesehatan masyarakat (selama bertahun-tahun, namun penurunan prevalensinya masih sangat rendah. ${ }^{1}$ Berdasarkan hasil Riskesdas 2018 diketahui prevalensi anemia pada ibu hamil sebesar 48,9\% dengan usia yang paling banyak mengalami anemia pada usia 15-24 tahun (84,6\%). ${ }^{2}$ Anemia merupakan suatu keadaan kadar hemoglobin $(\mathrm{Hb})$ dalam darah berada dibawah normal yang diakibatkan oleh defisiensi salah satu atau beberapa zat gizi yang dibutuhkan dalam pembentukan sel darah merah. Kelompok yang rentan terhadap anemia adalah tenaga kerja wanita yang disebabkan oleh kurangnya asupan zat gizi dan juga haid yang dialami WUS setiap bulannya berpengaruh terhadap kadar hemoglobin dan produktivitas pada pekerja. ${ }^{3}$ Anemia yang terjadi pada WUS dapat menimbulkan dampak bagi kesehatan dan performa kerja seperti kelelahan dan penurunan kapasitas kerja. Wanita dengan kondisi anemia juga lebih rentan berisiko terkena penyakit dibandingkan dengan yang tidak anemia. ${ }^{4}$

Anemia yang terjadi pada tenaga kerja wanita masih cukup tinggi. Berdasarkan hasil penelitian Khatun et al, tenaga kerja wanita mengalami anemia ringan sebesar 19\% (10,0-11,9 g/dl), anemia sedang sebesar $50 \%(7,0-9,9 \mathrm{~g} / \mathrm{dl})$, dan anemia berat sebesar $8 \%(<7,0 \mathrm{~g} / \mathrm{dl}) .{ }^{5}$ Masalah anemia tersebut diakibatkan oleh stres karena bekerja, gangguan kesehatan akibat faktor ekonomi, gangguan kesehatan reproduksi dan masalah gizi. ${ }^{6}$ Salah satu masalah yang dapat memengaruhi produktivitas kerja terutama pada pekerja wanita adalah anemia gizi.

Indonesia menunjukkan terdapat hampir 40 juta pekerja perempuan dan 25 juta diantaranya dalam usia produktif. ${ }^{7}$ Berdasarkan penelitian oleh Balai Besar Kesehatan Masyarakat Bogor di beberapa industri menengah dan besar di Kabupaten Bogor diketahui $40 \%$ pekerja perempuan mengalami anemia. Salah satu penyebabnya, karena mereka tidak mengonsumsi makanan bergizi. Hal ini dikarenakan upah yang mereka terima masih rendah. Anemia gizi yang melanda para pekerja wanita itu mengakibatkan produktivitas kerja mereka menjadi rendah. ${ }^{8}$ Rendahnya status kesehatan dan gizi pekerja perempuan disebabkan oleh rendahnya tingkat pendidikan mereka. Hal ini se- suai dengan data BPS tahun 2010 yang menunjukkan $50,37 \%$ pekerja perempuan berpendidikan SD ke bawah.

Anemia Defisiensi Besi (ADB) adalah anemia yang timbul akibat berkurangnya penyediaan besi untuk eritropoesis karena cadangan besi kosong (depleted iron store) yang pada akhirnya mengakibatkan pembentukan hemoglobin berkurang. ${ }^{9}$ Anemia bentuk ini merupakan bentuk anemia yang sering ditemukan di dunia, terutama di negara yang sedang berkembang. Anemia defisiensi besi lebih sering ditemukan di negara yang sedang berkembang sehubungan dengan kemampuan ekonomi yang terbatas, masukan protein hewani yang rendah, dan investasi parasit yang merupakan masalah endemik. ${ }^{10}$ Penelitian di Kota Tanggerang menunjukkan bahwa anemia berkaitan dengan tingkat kecukupan dan bioavailabilitas zat besi, yaitu rendahnya konsumsi kacang-kacangan, sayuran, buah-buahan dan lauk hewani. ${ }^{11}$

Pekerja di pabrik maupun di perkebunan yang merupakan wanita usia subur banyak mengalami masalah gizi. Pekerja wanita tersebut ditempatkan di bagian pengambilan/pemetikan daun teh dan pengolahan. Pekerja WUS tersebut sebagian besar melakukan pekerjaannya di lapangan, dengan berdiri dan berjalan sambil membawa hasil dari petikannya (kegiatan fisiknya tergolong aktif). Selama melakukan pekerjaannya di perkebunan teh, mereka memerlukan kebugaran fisik yang cukup baik karena berada di perkebunan yang luas dalam kondisi cuaca yang panas. Kondisi ini dikhawatirkan lama-kelamaan akan mengurangi kebugaran fisik dan berakibat pada menurunnya produktivitas kerja. Hal ini sesuai dengan penelitian Markurat et al, yang menyatakan pekerja wanita di Kamboja termasuk kelompok dengan risiko tinggi terhadap kekurangan gizi dengan kekurangan zat besi sebesar $22,1 \%$ dan anemia sebesar $26,9 \% .{ }^{12}$ Hal tersebut dikarenakan status gizi yang buruk berkontribusi terhadap prevelensi anemia secara keseluruhan, sehingga diperlukan strategi untuk meningkatkan status gizi, terutama peningkatan asupan zat gizi mikro. Studi Ganapathi \& Kumar melaporkan bahwa prevalensi keseluruhan anemia pada wanita kelompok usia reproduksi 15-49 tahun ditemukan 53,3\%. Prevalensi anemia menurun dengan bertambahnya usia dan ditemukan signifikan secara statistik. ${ }^{13}$ Penelitian 
ini bertujuan menganalisis faktor risiko yang memengaruhi terjadinya anemia pada wanita pemetik teh di daerah Pengalengan Bandung, Jawa Barat.

\section{BAHAN DAN METODE}

Penelitian dilakukan di PTPN VIII Perkebunan Teh di daerah Pengalengan Bandung, Jawa Barat, meliputi Kebun Purbasari, Talun Santosa dan Sedep pada bulan April-Mei 2016. Desain penelitian ini cross sectional dan bagian dari penelitian yang didanai oleh Neys-van Hoogstraten Foundation dengan tema Income contribution, food consumption, iron deficiency anemia among women workers in tea plantation and effect of multinutrients suplementation with nutrition education to increase their well-being dan mendapatkan persetujuan Etik (Ethical Approval) dari Komisi Etik Penelitian Kesehatan Fakultas Kesehatan Masyarakat Universitas Diponegoro Nomor: 22/ EC/FKM/2015.

Pemilihan subjek dalam penelitian ini melalui purposive tanpa pengembalian. Subjek berjumlah 148 orang pekerja Wanita Usia Subur (WUS) berusia antara 18-45 tahun yang sudah menikah dan tidak sedang hamil. Data yang dikumpulkan dalam penelitian ini meliputi karakteristik subjek (usia, besar keluarga, lama dan tingkat pendidikan), pengeluaran pangan dan non pangan keluarga/bulan, status gizi dan komposisi tubuh, dan status anemia.

Cara pengumpulan data karakteristik subjek, pengeluaran pangan dan non pangan keluarga adalah dengan menggunakan alat bantu kuesioner melalui teknik wawancara langsung oleh enumerator kepada subjek. Tinggi badan diukur dengan menggunakan microtoise merk GEA ${ }^{\circledR}$ buatan Indonesia dengan akurasi $0,1 \mathrm{~cm}$, berat badan diukur dengan menggunakan timbangan skala digital merk CAMRY ${ }^{\circledR}$ EB. 9374 buatan Cina dengan akurasi $0,1 \mathrm{~kg}$. Indeks Massa Tubuh (IMT) dihitung dengan rumus berat badan $(\mathrm{kg})$ dibagi tinggi badan (m) kuadrat. Komposisi tubuh dinilai dengan menggunakan BIA (Bioelectrical Impedance Analysis).

Data yang dikumpulkan merupakan data primer yang diambil menggunakan daftar pertanyaan (kuesioner), observasi dan pengukuran serta analisis biokimiawi dengan pengambilan darah secara langsung dengan metode cyano- methamoglobin menggunakan EDTA sebagai anti koagulan. Data primer yang diperoleh meliputi karakteristik sosial, pengeluaran pangan dan nonpangan, status gizi, komposisi tubuh dan status anemia. Wawancara dilakukan langsung oleh peneliti dibantu asisten peneliti bergelar sarjana gizi yang sudah berpengalaman dalam beberapa penelitian sebelumnya serta diberi pelatihan sebelum melakukan wawancara dalam penelitian ini untuk mengendalikan kualitas data.

Data awal dientry terlebih dahulu kemudian dilakukan cleaning untuk melihat kelengkapan dari seluruh kuesioner. Setelah selesai, kemudian dilakukan proses pengolahan data yang mencakup pengeditan kuesioner, pengkodean, penyusunan file, pemasukan data, pengeditan file, penyusunan variabel, pengkombinasian dan pemisahan file. Pengolahan data dan analisis menggunakan program komputer Microsoft Excel serta SPSS for Windows. Faktor risiko anemia dihitung menggunakan analisis regresi logistik $(\mathrm{p}<0.05)$. Kategori anemia yaitu jika konsentrasi $\mathrm{Hb}<120 \mathrm{~g} / \mathrm{dl}$. Prevalensi anemia menjadi masalah kesehatan masyarakat jika mencapai lebih dari 5\%. Masalah anemia termasuk ringan jika prevalensinya sebesar $5-19,9 \%$, sedang $(20-40 \%)$ dan serius $(>40 \%){ }^{14}$

\section{Tabel 1. Karakteristik Sosial Responden}

\begin{tabular}{|c|c|c|}
\hline Karakteristik & $\mathbf{n}$ & $\%$ \\
\hline \multicolumn{3}{|l|}{ Umur (tahun) } \\
\hline $18-39$ & 30 & 20.3 \\
\hline $40-44$ & 68 & 45.9 \\
\hline $45-49$ & 50 & 33.8 \\
\hline Rata-rata $\pm \mathrm{SD}$ & \multicolumn{2}{|c|}{$42.2 \pm 5.3$} \\
\hline \multicolumn{3}{|l|}{ Besar keluarga (orang) } \\
\hline $\operatorname{Kecil}(\leq 4)$ & 107 & 72.3 \\
\hline Sedang (5-7) & 41 & 27.7 \\
\hline Rata-rata \pm SD & \multicolumn{2}{|c|}{$3.9 \pm 1.2$} \\
\hline \multicolumn{3}{|l|}{ Lama pendidikan (tahun) } \\
\hline$\leq 6$ & 133 & 89.9 \\
\hline$>6$ & 15 & 10.1 \\
\hline Rata-rata \pm SD & \multicolumn{2}{|c|}{$5.3 \pm 2.0$} \\
\hline \multicolumn{3}{|l|}{ Tingkat pendidikan } \\
\hline Tidak sekolah & 56 & 37.8 \\
\hline SD & 78 & 52.7 \\
\hline SMP & 13 & 8.8 \\
\hline SMA & 1 & 0.7 \\
\hline
\end{tabular}


HASIL

Tabel 1 menunjukkan sebaran karakteristik umur, besar keluarga, lama pendidikan, dan tingkat pendidikan responden. Sebagian besar responden berumur 40-44 tahun (45.9\%). Rata-rata umur responden adalah 42,2 $\pm 5,3$ tahun. Pekerja ini memiliki peran ganda, yaitu sebagai ibu rumah tangga dan juga sebagai pekerja, dan keduanya harus dilaksanakan dengan baik. Semakin besar jumlah anggota keluarga maka akan semakin besar pula tanggung jawabnya. Kategori besar keluarga diperoleh sebanyak 72,3\% yang memiliki jumlah anggota keluarga kecil (antara 1-4 orang), dan sisanya sebanyak $27,7 \%$ merupakan keluarga besar. Secara umum, rata-rata anggota keluarga adalah $3,9 \pm 1,2$ orang. Kategori lama pendidikan pada tabel 1 menunjukkan $89,9 \%$ pekerja memperoleh pendidikan kurang atau sama dengan 6 tahun dan rata-rata lama pendidikan responden adalah $5,3 \pm 2,0$ tahun.

Total pengeluaran rumah tangga seperti ditunjukkan pada tabel 2 terbagi menjadi dua, yaitu pengeluaran pangan dan pengeluaran nonpangan. Total pengeluaran pangan sebesar $\mathrm{Rp}$ 1.133 .182 /bulan $(47,3 \%$ dari total pengeluaran rumah tangga) dan pengeluaran non pangan sebesar Rp 1.262.177/bulan (52,7\% dari total pengeluaran rumah tangga). Hasil tersebut menunjukkan pengeluaran non pangan lebih besar dibandingkan dengan pengeluaran pangan, dikarenakan penelitian dilakukan pada masa awal masuk sekolah sehingga pengeluaran untuk pendidikan, uang saku anak, serta jajanan meningkat. Selain itu, pengeluaran untuk kebiasaan merokok yang sulit untuk dihindari. Urutan pengeluaran pangan terbesar terdapat pada jajanan $(13,4 \%)$, makanan pokok $(13,2)$, sayur $(10,5 \%)$, lauk pauk $(8,7 \%)$, dan buah $(1,5 \%)$. Sedangkan, urutan pengeluaran non pangan terbesar terdapat pada rokok sebesar $(13,7 \%)$, pendidikan anak termasuk uang saku $(10,2 \%)$, dan cicilan/kredit/arisan $(9,0 \%)$.

Tabel 3 menunjukkan parameter status gizi antropometri pemetik teh yang diukur dengan IMT, lingkar lengan atas, total lemak tubuh, visceral fat, lingkar pinggang, lingkar pinggul, dan rasio pinggang pinggul. Berdasarkan berbagai indikator komposisi tubuh (IMT, total lemak tubuh, lingkar pinggang dan RPP), secara umum pekerja wanita pemetik teh rata-rata dalam kondisi berat badan berlebih (overweight dan obesitas). IMT yang diperoleh pada pekerja wanita pemetik teh menunjukkan bahwa sekitar 39,9\% tergolong obese dan 16,9\% overweight.

Rata-rata lemak tubuh responden adalah $32,1 \%$, dan proporsi lemak tubuh yang optimal hanya dijumpai pada $2,7 \%$ responden, selebihnya

Tabel 2. Rata-Rata Pengeluaran Pangan dan Non Pangan (Rp/bulan)

\begin{tabular}{lcc}
\multicolumn{1}{c}{ Jenis Pengeluaran } & Rupiah & \% \\
\hline Pengeluaran Pangan & & \\
Makanan pokok (belanja di pasar) & 316155 & 13.2 \\
Lauk pauk (ayam, ikan, daging, telur) & 209536 & 8.7 \\
Sayur & 250994 & 10.5 \\
Buah & 36421 & 1.5 \\
Jajanan & 320075 & 13.4 \\
Total Pengeluaran Pangan & 1133182 & 47.3 \\
Pengeluaran Non-Pangan & & \\
Kesehatan/Pengobatan & 62790 & 2.6 \\
Rokok & 329236 & 13.7 \\
Kebersihan (sabun cuci, sabun mandi, pasta gigi, dll) & 91945 & 3.8 \\
Bahan Bakar (gas, listrik, dan bensin) & 184798 & 7.7 \\
Pendidikan anak termasuk uang saku & 244263 & 10.2 \\
Pakaian & 93207 & 3.9 \\
Pulsa & 40474 & 1.7 \\
Cicilan/kredit/arisan & 215459 & 9.0 \\
Total Pengeluaran Non-Pangan & 1262177 & 52.7 \\
Pengeluaran Total & 2395359 & 100.0 \\
\hline Pengeluaran Perbulan perkapita & $664826 \pm 314202$ \\
\hline
\end{tabular}


Tabel 3. Sebaran Responden Berdasarkan Status Gizi dan Komposisi Tubuh

\begin{tabular}{|c|c|c|}
\hline Karakteristik & $\mathbf{n}$ & $\%$ \\
\hline \multicolumn{3}{|l|}{ Indeks Massa Tubuh (kg/m²) } \\
\hline Kurus (IMT < 18.5) & 2 & 1.4 \\
\hline Normal (IMT 18.5-24.9 & 62 & 41.9 \\
\hline Overweight (IMT 25.0-26.9) & 25 & 16.9 \\
\hline Obese (IMT $\geq 27)$ & 59 & 39.9 \\
\hline Rata-rata $\pm \mathrm{SD}$ & \multicolumn{2}{|c|}{$26.1 \pm 3.9$} \\
\hline \multicolumn{3}{|l|}{ Lingkar lengan atas (cm) } \\
\hline Normal & 146 & 98.6 \\
\hline KEK & 2 & 1.4 \\
\hline Rata-rata \pm SD & \multicolumn{2}{|c|}{$29.0 \pm 2.8$} \\
\hline \multicolumn{3}{|l|}{ Total lemak tubuh (\%) } \\
\hline Optimal (13-23) & 4 & 2.7 \\
\hline Slightly overfat (24-27) & 23 & 15.5 \\
\hline Fat $(28-32)$ & 42 & 28.4 \\
\hline Obes $(>32)$ & 79 & 53.4 \\
\hline Rata-rata \pm SD & \multicolumn{2}{|c|}{$32.1 \pm 4.7$} \\
\hline
\end{tabular}

\begin{tabular}{lcc}
\hline Visceral Fat (\%) & & \\
Normal $(\leq 9)$ & 96 & 64.9 \\
Increased risk $(10-15)$ & 7 & 30.4 \\
High risk $(>15)$ & 4.7 \\
\hline Lingkar pinggang (cm) & & \\
Tidak berisiko (LP $<80)$ & 63 & 42.6 \\
Berisiko (LP $\geq 80)$ & 85 & 57.4 \\
\hline Rata-rata \pm SD & \multicolumn{3}{c}{$82.9 \pm 10.8$} \\
\hline
\end{tabular}

\begin{tabular}{lcc}
\hline Lingkar pinggul $(\mathbf{c m})$ & \multicolumn{3}{c}{} \\
Rasio lingkar pinggang/pinggul & & \\
Tidak berisiko $(\mathrm{WHR}<0.8)$ & 28 & 18.9 \\
$\quad$ Berisiko (WHR $\geq 0.8)$ & 120 & 81.1 \\
\hline Rata-rata \pm SD & \multicolumn{3}{c}{$0.9 \pm 0.1$} \\
\hline
\end{tabular}

cenderung kelebihan lemak tubuh. Lemak visceral merupakan bentuk lemak yang berisiko terhadap munculnya penyakit kronis. Pada Tabel 3 dapat dilihat bahwa rata-rata visceral adalah $8,4 \%$. Wanita pemetik teh yang memiliki lemak visceral 10$15 \%$ berjumlah $30,4 \%$ dan yang memiliki lemak visceral lebih dari $15 \mathrm{~cm}$ berjumlah $4,7 \%$. Nilai rataan lingkar pinggang (waist) pekerja wanita pemetik teh adalah $82,9 \mathrm{~cm}$. Ukuran Rasio Pinggang-Pinggul (RPP) yang ideal bagi wanita adalah dibawah 0,80. Berdasarkan Tabel 3, RPP pekerja wanita yang tidak berisiko sebanyak $18,9 \%$, sedangkan yang diatas 0,80 (berisiko obesitas) sebesar $81,1 \%$. Rata-rata RPP adalah sebesar $0,9 \pm 0,1$. Tabel 4 menunjukkan status anemia berdasarkan pemeriksaan menggunakan metode cyanmethe-
Tabel 4. Sebaran Responden Berdasarkan Status Anemia

\begin{tabular}{lcc}
\hline \multicolumn{1}{c}{ Status Anemia } & n & \% \\
\hline Normal $(\mathrm{Hb} \geq 12.0 \mathrm{~g} / \mathrm{dL})$ & 85 & 57.4 \\
Anemia $(\mathrm{Hb}<12.0 \mathrm{~g} / \mathrm{dL})$ & 63 & 42.6 \\
\hline Rata-rata kadar $\mathrm{Hb} \pm \mathrm{SD}$ & \multicolumn{2}{c}{$12.2 \pm 1.2$} \\
\hline
\end{tabular}

moglobin. Hasil tersebut menunjukkan bahwa prevalensi anemia pada wanita pemetik teh sebanyak 42,6\% ditunjukkan dengan kadar hemoglobin dibawah 12,0 g/dl Hasil uji regresi logistik faktor risiko anemia menunjukkan bahwa nilai p-value kurang dari 0,05 didapatkan pada variabel overweight dengan nilai OR nilai 0,030 dan 4,119; 95\% CI: 1,143-14,839 (Tabel 5).

\section{PEMBAHASAN}

Hasil penelitian menunjukkan wanita pemetik teh memiliki tingkat pendidikan yang rendah, ditunjukkan dari sebagian besar wanita pemetik teh memperoleh pendidikan kurang dari 6 tahun dan kebanyakan wanita pemetik teh menyelesaikan pendidikannya pada tingkat sekolah dasar. Tingkat pendidikan memegang peranan yang penting, semakin tinggi pendidikan seseorang maka akan semakin mudah dalam berpikir sehingga dapat menyelesaikan tugasnya dengan baik. ${ }^{15}$ Hal ini sejalan dengan penelitian yang dilakukan oleh Mariza yang mendapatkan hasil bahwa terdapat hubungan antara tingkat pendidikan dengan kejadian anemia, yaitu sebanyak $78,6 \%$ subjek berpendidikan rendah mengalami anemia. ${ }^{16} \mathrm{Se}-$ makin tinggi tingkat pendidikan (lama sekolah) seseorang, semakin mudah menerima hidup sehat secara mandiri, kreatif, dan berkesinambungan. Oleh karena itu, tingkat pendidikan mempunyai hubungan yang eksponensial terhadap status gizi dan kesehatan. ${ }^{17}$

Pengeluaran rumah tangga merupakan salah satu indikator kesejahteraan rumah tangga di suatu wilayah. Selama ini, diketahui bahwa besar kecilnya proporsi pengeluaran untuk konsumsi makanan terhadap seluruh pengeluaran rumah tangga dapat memberikan gambaran kesejahtera- an rumah tangga tersebut. Rumah tangga dengan proporsi pengeluaran biaya pangan lebih besar untuk konsumsi makanan mengindikasikan rumah tangga tersebut berpenghasilan rendah. 
Tabel 5. Analisis Regresi Logistik Faktor Risiko Anemia

\begin{tabular}{|c|c|c|}
\hline Karakteristik & p-value & OR (CI 95\%) \\
\hline \multicolumn{3}{|l|}{ Umur (tahun) $\quad(45-49=0)$} \\
\hline $18-39$ & 0.040 & $0.290(0.089-0.944)$ \\
\hline $40-44$ & 0.795 & $1.125(0.0465-2.721)$ \\
\hline \multicolumn{3}{|l|}{ Lama pendidikan (tahun) $(>6=0)$} \\
\hline$\leq 6$ & 1.000 & $912644479.256(0.000)$ \\
\hline \multicolumn{3}{|l|}{ Tingkat pendidikan $(\mathrm{SMA}=0)$} \\
\hline Tidak sekolah & 1.000 & $0.526(0.000)$ \\
\hline SD & 1.000 & $0.719(0.000)$ \\
\hline SMP & 1.000 & $360643650.407(0.000)$ \\
\hline \multicolumn{3}{|l|}{ Besar keluarga (orang) $(\operatorname{Kecil}(\leq 4)=0)$} \\
\hline Sedang (5-7) & 0.323 & $0.621(0.242-1.597)$ \\
\hline \multicolumn{3}{|l|}{ Pengeluaran per kap (tidak miskin $=0$ ) } \\
\hline Miskin & 0.434 & $1.971(0.360-10.798)$ \\
\hline \multicolumn{3}{|c|}{ Indeks Massa Tubuh $\left(\mathbf{k g} / \mathbf{m}^{2}\right)($ Normal $($ IMT 18.5-24.9) $=0)$} \\
\hline Kurus (IMT < 18.5) & 0.999 & $449034683.138(0.000)$ \\
\hline Overweight (IMT 25.0-26.9) & 0.030 & $4.119(1.143-14.839)$ \\
\hline Obes (IMT $\geq 27)$ & 0.201 & $3.204(0.539-19.051)$ \\
\hline \multicolumn{3}{|l|}{ Lingkar lengan atas $(\mathbf{c m})($ Normal $=0)$} \\
\hline KEK & 0.658 & $2.093(0.079-55.243)$ \\
\hline \multicolumn{3}{|l|}{ Total lemak tubuh $(\%)($ Optimal $(13-23)=0)$} \\
\hline Slightly overfat (24-27) & 0.999 & $0.000(0.000)$ \\
\hline Fat (28-32) & 0.999 & $0.000(0.000)$ \\
\hline Obes $(>32)$ & 0.999 & $0.000(0.000)$ \\
\hline \multicolumn{3}{|l|}{ Visceral Fat (\%) $($ Normal $(\leq 9)=0)$} \\
\hline Increased risk (10-15) & 0.266 & $0.261(0.024-2.783)$ \\
\hline High risk $(>15)$ & 0.465 & $0.533(0.099-2.880)$ \\
\hline \multicolumn{3}{|c|}{ Lingkar pinggang $(\mathbf{c m})($ Tidak berisiko $(\mathrm{LP}<80)=0)$} \\
\hline Berisiko $(\mathrm{LP} \geq 80)$ & 0.265 & $0.446(0.108-1.843)$ \\
\hline \multicolumn{3}{|c|}{ Rasio lingkar pinggang/pinggul (Tidak berisiko (WHR $<0.8)=0$ ) } \\
\hline Berisiko (WHR $\geq 0.8$ ) & 0.583 & $1.432(0.398-5.157)$ \\
\hline
\end{tabular}

Makin tinggi penghasilan rumah tangga, maka makin kecil proporsi pengeluaran untuk pangan terhadap seluruh pengeluaran rumah tangga. $\mathrm{Ru}-$ mah tangga cenderung semakin sejahtera bila persentase pengeluaran untuk makanan lebih kecil dibandingkan persentase pengeluaran untuk non makanan. Pengeluaran rumah tangga dibedakan menurut kelompok pangan dan non pangan. ${ }^{18}$ Hasil penelitian menunjukkan pengeluaran pangan pada keluarga wanita pemetik teh lebih kecil jika dibandingkan dengan pengeluaran non pangan jenis pengeluaran non pangan yaitu meliputi kesehatan, rokok, kebersihan, bahan bakar, pendidikan anak, pakaian, pulsa, dan cicilan. Tiga pengeluaran non pangan teratas adalah rokok, pendidikan anak-anak, dan cicilan/kredit/arisan. Berdasarkan hasil penelitian Widyaji dan Mahmudiono ditemukan adanya hubungan pengelua- ran rumah tangga $(\mathrm{p}=0,016)$ dan asupan protein $(p=0,037)$ dengan kadar hemoglobin. ${ }^{19}$ Pengeluaran untuk kesehatan/pengobatan berada diurutan kedua terkecil dari jenis pengeluaran. Pengeluaran non pangan yang dihabiskan untuk rokok lebih besar dari pengeluaran untuk pangan pokok. Hal ini menunjukkan prioritas yang salah pada pengeluaran rumah tangga. Sebenarnya pengeluaran untuk rokok dapat diganti untuk membeli pangan sumber protein hewani yang memiliki bioavailabilitas besi yang lebih baik daripada pangan nabati. Pengeluaran tembakau setiap hari diasumsikan dapat menambah kebutuhan gizi pangan keluarga, sebagai contoh biaya yang digunakan untuk membeli 1 bungkus rokok setara dengan $0.5 \mathrm{~kg}$ daging ayam (975 kalori). Hal ini selaras dengan studi tentang pengelompokan anemia pada perempuan dan anak-anak di Indonesia yang menemukan bah- 
wa ayah yang merokok akan meningkatkan risiko terjadinya anemia di keluarga karena sumber daya keluarga dialihkan dari makanan ke tembakau. ${ }^{20}$ Efroymson yang mendukung analisis tentang dampak ekonomi dari konsumsi tembakau di kalangan masyarakat miskin di Bangladesh menyatakan bahwa pengeluaran rokok merupakan beban besar bagi rumah tangga miskin. ${ }^{21}$ Pengeluaran yang dihabiskan untuk rokok dapat dialihkan ke pengeluaran makanan dan kesehatan seperti yang ditegaskan oleh penelitian ini.

Rasio berat badan dan tinggi badan mengindikasikan berat badan dalam hubungannya dengan tinggi badan dan bermanfaat untuk mengukur kejadian overweight dan obesitas pada orang dewasa. Validitas indeks massa tubuh sebagai indeks persentase lemak tubuh sudah banyak diteliti dan dikatakan valid. ${ }^{22}$ Jumlah wanita pemetik teh yang mengalami overweight dan obesitas sebesar $56,8 \%$ menunjukkan besarnya masalah gizi yang dihadapi masyarakat di perkebunan teh. Overweight dan obesitas merupakan faktor risiko dari berbagai penyakit degeneratif, seperti: diabetes mellitus tipe 2, hipertensi, penyakit jantung, asma, gangguan mental, depresi, dislipidemia dan kanker. ${ }^{23}$ Menurut Nuttall peningkatan lemak visceral pada wanita seiring dengan meningkatnya umur berhubungan dengan penurunan sirkulasi estradiol yaitu penurunan estrogen/testosterone yang berhubungan dengan menopause. ${ }^{24}$ Akumulasi lemak di bagian atas tubuh juga berhubungan dengan peningkatan risiko penyakit jantung koroner, diabetes, batu ginjal dan gout dibandingkan dengan akumulasi lemak di tubuh bagian bawah. Wanita yang gemuk memiliki risiko yang lebih tinggi terkena penyakit diabetes dan penyakit jantung koroner, dan berbagai penyakit kanker. ${ }^{25}$ Ukuran rasio lingkar pinggang-pinggul (RPP) merupakan indikator status gizi penduduk usia dewasa untuk mengetahui adanya obesitas abdomen. Ukuran RPP memberikan pendugaan akumulasi lemak abdomen, karena peningkatan RPP dapat memprediksi peningkatan risiko penyakit jantung, diabetes dan penyakit kronis lainnya yang berkaitan dengan obesitas. ${ }^{26}$

Hasil penelitian ini menunjukkan bahwa yang berhubungan dengan anemia adalah variabel overweight sebagai faktor risiko dan umur sebagai faktor protektif (umur 18-39 tahun). Pada umur
18-39 tahun risiko terjadinya anemia akan lebih kecil dibandingkan dengan usia 40-44 tahun. Hal ini dikarenakan pada usia tersebut rentan mengalami penyakit kronis yang menimbulkan perubahan dalam fungsi tubuh khususnya pada mekanisme pembentukan sel darah merah dan penurunan hemoglobin, yang mengakibatkan terjadinya anemia. Hasil penelitian ini berbeda dengan studi yang dilakukan oleh Mulyawati yang menemukan bahwa dari 72 pekerja wanita di sebuah perusahaan Plywood di Jakarta ditemukan 56 orang $(77,77 \%)$ menderita anemia, dan sebanyak 54 subjek diantaranya tergolong kedalam usia reproduksi berkisar antara 19 sampai 35 tahun (dengan rata-rata 23 tahun). ${ }^{27}$ Prevalensi anemia pada wanita lebih besar dibandingkan dengan pria dikarenakan pada usia reproduksi, wanita harus mengalami haid setiap bulannya. Darah yang keluar pada waktu haid menyebabkan kehilangan zat besi 1,3 mg per hari. Pada kondisi tubuh overweight akan meningkatkan risiko terjadinya anemia sebesar 4,119 kali dibandingkan dengan IMT lainnya. Hal tersebut dikarenakan terdapat penimbunan lemak di jaringan adiposa. Penimbunan lemak ini dapat menurunkan penyerapan zat besi sehingga menyebabkan terjadinya inflamasi kronik yang berhubungan dengan ekspresi sitokin proinflamatory yang pada akhirnya mempengaruhi proses metabolisme besi sehingga akan terjadi radikal bebas. $\mathrm{Hal}$ ini menyebabkan sintesis $\mathrm{Hb}$ tidak sempurna dan pada akhirnya jumlah hemoglobin menurun dan eritrosit mengecil hingga dan terjadi anemia. ${ }^{28}$ Hal ini sejalan dengan penelitian Shekarriz dan Vaziri yang menyatakan ada hubungan positif antara peradangan serta overweight yang berpengaruh terhadap perubahan kadar $\mathrm{Hb}$ (anemia). ${ }^{29}$

Masalah kegemukan pada wanita pekerja ini dikhawatirkan akan meningkatkan risiko masalah kesehatan, sehingga pada akhirnya akan memengaruhi kapasitas dan produktivitas kerjanya. Berdasarkan penelitian Mayez et al, pada orang dengan kelebihan berat badan, terjadi penimbunan lemak yang berlebihan, sehingga terakumulasi di hati. Keadaan ini bermula dari peningkatan kadar asam lemak bebas sebagai katabolisme lemak dalam darah. Asam lemak bebas dengan jumlah yang meningkat akan diambil oleh hati dan produksi VLDL (Very Low Density Lipoprotein) tidak dapat mengikuti kecepatan aliran masuk asam lemak 
bebas sehingga terjadi penimbunan triasilgliserol yang akan menyebabkan timbunan lemak pada hati. Akumulasi keadaan ini dapat memicu pembentukan peroksida lipid yang pada akhirnya akan memengaruhi proses metabolisme besi sehingga akan terjadi radikal bebas. ${ }^{30}$

Menurut Lopez overweight dan obesitas berkaitan dengan kejadian anemia. Pada wanita yang kelebihan berat badan penyerapan zat besi dua pertiga lebih rendah dari wanita dengan berat badan normal karena tidak dapat memenuhi fungsi untuk membawa oksigen dalam jumlah yang cukup ke jaringan perifer. Sehingga, terjadinya gangguan pembentukan eritrosit oleh sumsum tulang. ${ }^{31}$ Survei yang dilakukan di negara Cina menunjukkan populasi wanita dengan kelebihan berat badan memiliki kemungkinan lebih kecil mengalami anemia dibandingkan dengan wanita dengan berat badan normal. ${ }^{32}$ Namun demikian, penelitian yang dilakukan oleh Pasalina menunjukkan bahwa persentase terbesar $(66,7 \%)$ penderita anemia adalah pada subjek dengan berat badan berlebih. ${ }^{33} \mathrm{Hal}$ ini sejalan dengan penelitian Zeng et al, yang menemukan bahwa terjadi peningkatan risiko anemia pada wanita yang overweight. ${ }^{34}$ Didukung pula dengan penelitian di Meksiko yang menunjukkan bahwa prevalensi defisiensi besi lebih tinggi pada wanita overweight dibandingkan dengan berat badan normal. Meskipun asupan zat besi sama, namun konsentrasi besi serum lebih rendah pada wanita overweight. Hal tersebut dikarenakan habisnya cadangan besi dan adanya penurunan supply besi ke dalam sumsum tulang. Sehingga produksi sel darah merah terganggu. ${ }^{35}$

\section{KESIMPULAN DAN SARAN}

Rata-rata pekerja wanita pemetik teh berusia 40-44 tahun dengan tingkat pendidikan rendah, dan jumlah keluarga $\leq 4$ orang. Rata-rata pengeluaran non pangan lebih besar daripada pengeluaran pangan. Berdasarkan berbagai indikator komposisi tubuh, secara umum pekerja wanita pemetik teh dalam kondisi berat badan berlebih (overweight dan obesitas) sebesar 56,8\%, lingkar lengan atas normal $(98,6 \%)$. Rata-rata total lemak tubuh $>32,1 \%$, visceral fat normal $(\leq 9 \%)$, lingkar pinggang berisiko $\geq 80 \mathrm{~cm}$, dan RPP (Rasio Pinggang Pinggul) $\geq 0,8 \mathrm{~cm}$ sebesar $81,1 \%$. Prevalensi anemia pada wanita pemetik teh sebesar $42,6 \%$.
Adapun faktor yang paling berpengaruh terhadap kejadian anemia adalah overweight sebagai faktor risiko dan umur sebagai faktor protektif. Overweight merupakan faktor yang paling berisiko terhadap anemia karena penimbunan lemak dapat menurunkan penyerapan zat besi sehingga jumlah hemoglobin menurun dan eritrosit mengecil. Overweight ini dapat dicegah melalui pola hidup sehat, menjaga Indeks Masa Tubuh (IMT) dalam kondisi normal, dan edukasi gizi untuk meningkatkan kesadaran masyarakat terkait pentingnya pencegahan overweight yang dapat menyebabkan anemia dan penyakit degeneratif lainnya.

\section{UCAPAN TERIMA KASIH}

Terima kasih penulis sampaikan kepada Neys-van Hoogstraten Foundation (NHF), The Netherlands yang telah memberikan bantuan penelitian melalui IPB pada penelitian yang merupakan rangkaian dari penelitian disertasi penulis.

\section{DAFTAR PUSTAKA}

1. [WHO] World Health Organization. The Global Prevalence of Anaemia in 2011. Geneva $(\mathrm{CH})$ : World Health Organization; 2015.

2. Riskesdas. Hasil Utama Riskesdas 2018. Jakarta: Kementerian Kesehatan Badan Penelitian dan Pengembangan Kesehatan; 2018.

3. Khatun K, Imbach P, Zamora JC. An Assessment of Climate Change Impacts on the Tropical Central America using the Holdridge Life Zone (HLZ) Land Classification System. iForest: Biogeosciences and Forestry. 2013; 6:183-189.

4. Widiastuti S. Faktor Determinan Produktivitas Kerja pada Pekerja Wanita. [Skripsi]. Semarang: Program Studi Ilmu Gizi Fakultas Kedokteran Universitas Diponegoro; 2016.

5. Khatun T, Alamin A, Saleh F, Hossain M, Hoque A, Ali L. Anemia among Garment Factory Workers in Bangladesh. Journal of Scientific Research. 2013;16(4): 502-507.

6. Kemenkes RI. Pedoman Gizi Seimbang. Jakarta: Ditjen Bina Gizi dan KIA Kementerian Kesehatan RI; 2014.

7. BPS. Jakarta Dalam Angka. Jakarta: Badan Pusat Statistik; 2012.

8. Gopaldas T. Iron-Deficiency Anemia in Young Working Women can be Reduced by 
Increasing the Consumption of Cereal-Based Fermented Foods or Gooseberry Juice at the Workplace. Food and Nutrition Bulletin. 2002;23(1):94-105.

9. Rammohan A, Awofeso N, Robitaille MC. Addressing Female Iron-Deficiency Anaemia in India: Is Vegetarianism the Major Obstacle. ISRN Public Health. 2012:1-8.

10. Faeris NS. Prevalence of Iron Deficiency Anemia Etiological and Prevention. European Journal Biology Medical Science Research. 2014;2(2):55-60.

11. Fitri YP, Briawan D, Tanziha I, Madanijah S. Tingkat Kecukupan dan Bioavailabilitas Asupan Zat Besi pada Ibu Hamil di Kota Tanggerang. Jurnal MKMI. 2016;12(3):185191.

12. Makurat J, Friedrich H, Kuong K, Wieringa FT, Chamnan C, Krawinkel MB. Nutritional and Micronutrient Status of Female Workers in a Garment Factory in Cambodia. Journal Nutrients. 2016;8(11):1-16.

13. Ganapathi CK, dan Kumar SK. A Cross-Sectional Study of Anemia Among Women of Reproductive Age Group (15-49 Years) in a Rural Population of Tamil Nadu. Int J Med Sci Pub Health. 2016;6(3).

14. [UNICEF/UNU/WHO] United Nations Children's Fund, United Nations University, World Health Organization. Iron Deficiency Anaemia Assessment, Prevention, and Control:A Guide for Programme Managers. Geneva $(\mathrm{CH})$ : World Health Organization; 2001.

15. Setyawati LM. Selintas Tentang Kelelahan Kerja. Yogyakarta: Amara; 2010.

16. Mariza, Ana. Hubungan Pendidikan dan Sosial Ekonomi dengan Kejadian Anemia pada Ibu Hamil di BPS T Yohan Way Halim Bandar Lampung Tahun 2015. Jurnal Kesehatan Holistik. 2016;10(1):5-8.

17. Fifi ML, Nova H, Kapantaw, Nancy M. Hubungan antara Status Ekonomi dengan Anemia Ibu Hamil di Desa Sapa Kecamatan Tengah Kabupaten Minahasa Selatan. [Tesis]. Manado: Fakultas Kesehatan Masyarakat Universitas Samratulangi; 2012.

18. Arida A, Sofyan, Fadhiela K. Analisis Ketahanan Pangan Rumah Tangga berdasarkan Proporsi Pengeluaran Pangan dan Konsumsi En- ergi. Agrisep. 2015;16(1):20-34.

19. Widyaji dan Mahmudiono. Hubungan Pengeluaran Rumah Tangga, Asupan Protein dan Asupan Zat Besi dengan Kadar Hemoglobin pada Pekerja Tambang Pasir Tradisional. Amerta Nutrion. 2017;1(3):220-226.

20. Souganidis ES, Sun K, de Pee S, Kraemer K, Rah JH, Moench-Pfanner R, Sari M, Bloem MW, Semba RD. Relationship of Maternal Knowledge of Anemia with Maternal and Child Anemia and Health-Related Behaviors Targeted at Anemia Among Families in Indonesia. Maternal and Child Health Journal. 2012;16(9):1913-1925.

21. Efroymson D, Ahmed S, Twonsend J. Hungry for Tobacco: An Analysis of the Economic Impact of Tobacco Consumption on the Poor in Bangladesh. BMJ Journals: Tobacco Control. 2001;10(3):212-217.

22. Gibson RS. Principles of Nutritional Assessment. Second edition: New York. Oxford [UK]: Oxford University Press; 2005.

23. Yaghoobi M, Rimaz S, Aebabisarjou A, Liaghat S, Salehiniya H. The Prevalence of Obesity and Overweight in Iranian Women: A Study in Zahedan (Southeast of Iran). Scholars Journal Applied Medical Sciences (SJAMS). 2015; 3(3F):1411-1415.

24. Nuttall FQ. Body Mass Index. Nutrition Today. 2015;50(3):117-128.

25. Kulie T, Slattengren A, Redmer J, Counths H, Englash A, Schrager S. Obesity and Women's Health: An Evidence-Based Review. Journal of the American Board of Family Medicine. 2011;24(1):75-85

26. Rucker D, Padwal R, Li SK, Lau DCW. Canadian Clinical Practice Guidelines on the Management and Prevention of Obesity in Adults and Children. CMAJ. 2007;176(8):1-13.

27. Mulyawati Y. Perbandingan Efek Suplementasi Tablet Tambah Darah dengan dan Tanpa Vitamin C terhadap Kadar Hemoglobin pada Pekerja Wanita di Perusahaan Plywood [Tesis]. Jakarta: Program Pasca Sarjana UI; 2003.

28. Nagababu E, Gulyani S, Earley CJ, Cutler RG, Mattson MP, Rifkind JM. Iron-Deficiency Anemia Enhances Red Blood Cell Oxidative Stress. Free Radical Research. 2008; 42(9):824-829. 
29. Shekarriz R, Vaziri MM. Iron Profile and Inflammatory Status of Overweight and Obese Women in Sari, North of Iran. International Journal of Hematology Oncolgy and Stem Cell Research. 2017;11(2):108-113.

30. Mayez MD, Lacey JV Jr, Beebe-Dimmer J, Gillespie BW, Cooper B, Laing TJ, Schottenfeld D. Prevalence, Incidence, Survival, and Disease Characteristics of Sistemic Sclerosis in a large US population. Arthritis \& Rheumatism. 2003; 48(8):2246-2255.

31. Lopez AC, Melseboonstra A, MB, HerterAeberli I. In Overweight and Obese Women, Dietary Iron Absorption is Reduced and the Enhancement of Iron Absorption by Ascorbic Acid is one Half that in Normal-Weight Women. The American Journal of Clinical Nutrition. 2015;102(6):1389-1397.

32. Anderson AK. Prevalence of Anemia, Overweight/Obesity, and Undiagnosed Hypertension and Diabetes among Residents of Se- lected Communities in Ghana. International Journal of Chronic Disseases. 2017;1-7.

33. Pasalina PE, Jurnalis YD, Ariadi. Hubungan Indeks Massa Tubuh dengan Kejadian Anemia pada Wanita Usia Subur Pranikah. Jurnal Ilmu Keperawatan dan Kebidanan. 2019; 10(1):12-20.

34. Zeng Q, He Yuan, Dong S, Zhao X, Chen Z, Song Z, Chang G, Yang F, Wang Y. Optimal Cut-Off Values of BMI, Waist Circumference and Waist: Height Ratio for Defining Obesity in Chinese Adults. British Journal Nutrition. 2014;112(10):1735-1744.

35. Lopez AC, Osendarp SJM, Boonstra AM, Aeberli I, Salazar FG, Feskens E. Sharply Higher Rates of Iron Deficiency in Obese Women and Children are Predicted by Obesity-Related Inflammation Rather than by Differences in Dietary Iron Intake. The American Journal Clinical Nutrition. 2011;93(5):975-983. 